\title{
ANALYSIS OF INTERNAL EMIGRATION IN POLAND USING THE SPATIAL DYNAMIC SHIFT-SHARE METHOD
}

The main aim of this paper is to examine internal population movements in Poland, and in particular, the problems connected with population outflow to other areas of the country. The spatial dynamic shift-share method is used to analyse the internal emigration of the population (deregistrations for permanent stay in other subregions) according to the gender and migration direction (urban, rural) criteria from 2000 to 2012. Therefore, the study analyses the pace of changes in the volume of the phenomenon as well as the share and identification of the structural and regional factors (local, spatial) in the size of the global effect of deregistrations in specific subregions. Moreover, it takes into consideration a spatial weights matrix allowing to include the spatial aspects in the study.

Keywords: Spatio-temporal analysis, spatial dynamic shift-share, migration, internal emigration

JEL: C49, O15

DOI: $10.15611 /$ aoe.2015.2.07

\section{INTRODUCTION}

The migration processes in Poland were usually connected with the country's political situation. The partitions of Poland, World Wars I and II, Martial Law, Poland's accession to the Schengen Area and the European Union significantly affected migration movements ${ }^{1}$. They resulted in both international migrations (departures of individuals abroad) and internal migrations (movements of individuals within the territory of the country). Internal migration substantially increased in Poland in the post-war period when people moved from overpopulated rural to urban areas where industry developed. As a consequence, the percentage of the population living in

\footnotetext{
* Faculty of Economics and Sociology, Department of Spatial Econometrics, University of Łódź

${ }^{1}$ Population migrationare movements of people connected with changing the place of residence (permanent residence or temporary stay) involving crossing the border of an administrative unit of territorial division of Poland (internal migration) or the national border (international migration), according to the Central Statistical Office of Poland, www.stat.gov.pl (20.02.2015).
} 
urban areas rose from $37 \%$ in 1950 to $56 \%$ in 1975 . This phenomenon stopped in the 1990s. At present we can see that an opposite process has been intensifying- people are settling in rural areas that surround cities and have lost their agricultural character (Kałuża-Kopias, 2010).

According to the Central Statistical Office definition, internal migration is a change of the place of residence of the population in the territory of the country, connected with crossing the administrative border of a 'gmina', or in the case of urban-rural gmina - a change of the place of residence within a gmina, i.e. from rural to urban areas and vice versa ${ }^{2}$. The specialist literature often refers to internal migration as population wandering. In turn, the terms, emigration and immigration, are used interchangeably with those of population outflow and population inflow.

The following migration can be distinguished as part of internal migration: intervoivodeship and intravoivodeship. It should be emphasized that intravoivodeship migration accounts for about $75 \%$ of the overall internal migration in Poland (Sasin, 2011). Thus the largest population movements occur at the levels of 'gmina', 'powiat' and subregion. The most important directions of population flow within Poland are also movements between urban areas, between urban and rural areas (in both directions) and migration forced by the labour market.

The age of migrants is currently decreasing. Young people (of working age) with no commitments or experience in the labour market are more willing to migrate (European Urban Knowledge Network, 2012). As for internal migration, these are predominantly individuals for whom work is consistent with their education and thus the opportunity for advancement (improved material or social status) is a priority. It is also worth noting that, in contrast to international migration, females clearly predominate among internal migrants (Migration for economic reasons and return migration in Poland..., 2009). This trend mainly concerns migration to big cities and is among the major causes of the reduced demographic potential of rural areas (International Organization for Migration, 2005).

The principal causes of internal migration in Poland include so called familial matters (entering into or the breakdown of marriage and family reunification), housing conditions (eviction, excessive cost of living, desire to live in better conditions) and work (a better job offer, loss of employment, arduous commuting, long-term unemployment). Currently there is a trend among the well-off to move to the outskirts of big cities in order to raise

\footnotetext{
${ }^{2}$ http://www.stat.gov.pl/cps/rde/xbcr/gus/migracje_wewnetrzne_ludnosci.pdf (03.09.2013).
} 
their standard of living - improve the environmental and housing conditions. Migration for permanent residence is most commonly caused by marriage and housing conditions ( $75 \%$ of all internal migrations). As for temporary migration, the primary cause is changing jobs and education. It should be stressed that, as opposed to international migration, non-economic factors are the most common motive behind internal population flow in Poland (Stelmachowicz-Pawyza, Świerzakowska-Ambroziak, 2009).

The advantages of population movement within the country undoubtedly include: the better allocation of the workforce contributing to economic growth and reduced unemployment, the increased individual incomes of the population and improved living conditions. Population movements, however, and emigration in particular, lead to adverse demographic consequences for Poland. A large population outflow causes the depopulation of some areas. Leaving territorial units by the young adversely affects the demographic structure, resulting in a falling birth rate and the accelerated process of the aging of the society. Population outflow to urban areas results in the breakdown of local rural communities, the disappearance of old-time interpersonal relations and traditions (Stelmachowicz-Pawyza, Świerzakowska-Ambroziak K., 2009).

The mobility of Poles is high at international level but relatively low domestically. An alternative to internal migration in Poland is the so called shuttle movement of the population associated with daily commuting. Although commuting often takes long and is arduous, it allows one to avoid stress, risk and cost connected with moving out.

Issues of internal population movements in Poland, and in particular, problems connected with population outflow to other areas of the country, have not been exhaustively discussed in the specialist literatures so far. Hence, the need exists for more in-depth studies in that field with the use of appropriate research tools. The main aim of the article is to apply the spatial dynamic shift-share method in the analysis of the internal emigration of the population (deregistrations for permanent stay in other subregions) according to the gender and migration direction (urban, rural) criteria from 2000 to 2012. Therefore, the study analyses the pace of changes in the volume of the phenomenon as well as the share and identification of structural and regional factors (local, spatial) in the size of the global effect of deregistrations in specific subregions. Moreover, it takes into consideration a spatial weights matrix allowing to include spatial aspects in the study. 


\section{STATISTICAL DATA - PRELIMINARY ANALYSIS}

One of the most debatable areas in migration analysis is the quality of statistical data. This problem concerns to a larger extent international migration. Nevertheless, the quality of data about internal migration is not satisfactory either. According to the above-quoted Central Statistical Office definition, a change of the place of residence (moving) equals a change of the place of registration. Thus, the published statistical data are not comprehensive. They do not take into account the increasingly popular phenomenon of the so called circulation of population, i.e. territorial movement that does not entail a relatively permanent change of the place of residence. It is a well-known fact that a considerable part of society stays permanently or temporarily in a place other than their place of registration. Such new forms of migration make the statistical assessment of the phenomenon more and more difficult. Currently, statistical knowledge and practice seem to be falling behind contemporary mobility processes (Kaczmarczyk, Tyrowicz, 2007). Nonetheless, being fully aware that available data do not record everything (they suffer from deficiencies we cannot overcome), we should emphasize their value. Due to the need to analyse and asses the level of internal population movements in Poland, the study was performed on statistical data published by the Central Statistical Office.

The analysis of internal emigration in Poland was carried out based on statistical data concerning the number of deregistrations due to departures to urban or rural areas of other subregions according to gender from 2000 to 2012. Hence, the statistical data bank has four dimensions - the direction of migration taking into account not only the subregion but also its character (urban, rural), gender and years.

Preliminary statistical data analysis indicates that the lowest overall number of deregistrations due to departure to other subregions in Poland was observed in 2001 (269,282 individuals). In subsequent years the level of the variable rose to reach a peak of 360,885 in 2007, while 2008 saw the largest drop in the value of the variable over the whole period. From 2008 to 2010 the number of deregistrations was at about 300,000 individuals and fell slightly in 2011. Figure 1 shows that females displayed greater mobility. The biggest difference in the number of deregistrations between females and males was observed in 2009 (26,754 individuals), while the lowest - in 2001 $(14,170$ individuals).

In the analysed period, the population outflow to urban areas definitely predominated (urban-urban, rural-urban). The biggest difference between deregistrations due to departure to urban and rural areas was noted in 2002 


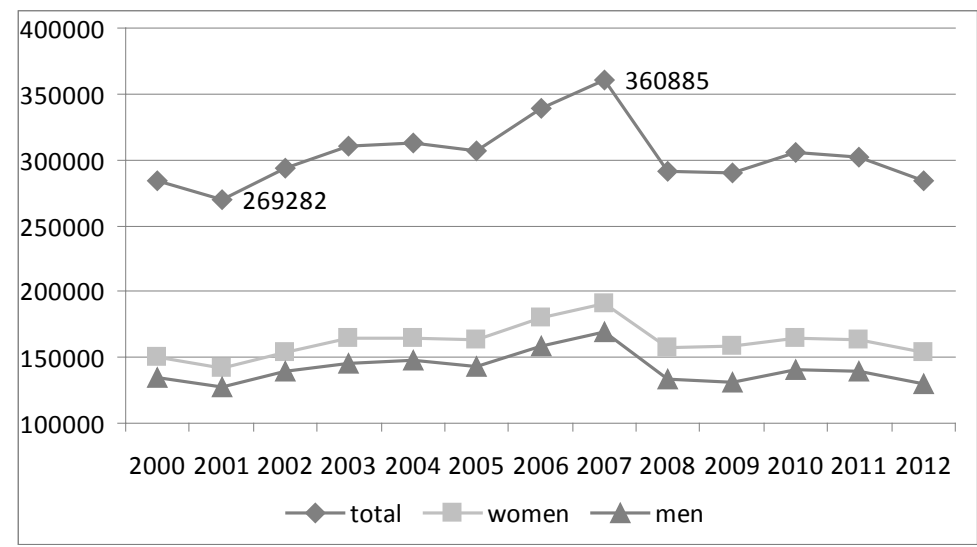

Figure 1. Number of deregistrations due to departure to other subregions in general in Poland and according to gender from 2000 to 2012

Source: authors' elaboration

$(72,883)$. From 2007 to 2012 the difference was steadily declining to about 52,000 in 2012. Figure 2 clearly shows that both the variables were quite considerably differentiated over the studied period. The lowest number of deregistrations due to departure to both urban and rural areas was observed in 2001 and the highest - in 2007.

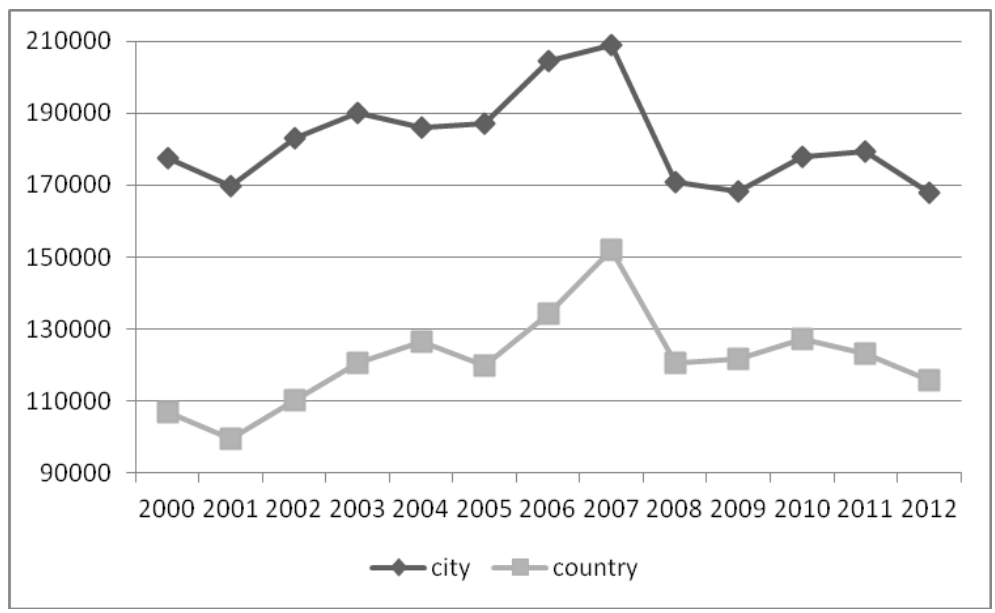

Figure 2. Number of deregistrations due to departure to urban and rural areas in Poland from 2000 to 2012

Source: authors' elaboration 
Figure 3 shows the spatial differentiation of overall population outflow to other subregions. Due to the limited length of the article, the maps present selected years of analysis - 2001 (the lowest values of the variable), 2007 (the highest values of the variable) and 2012 (the most current period).

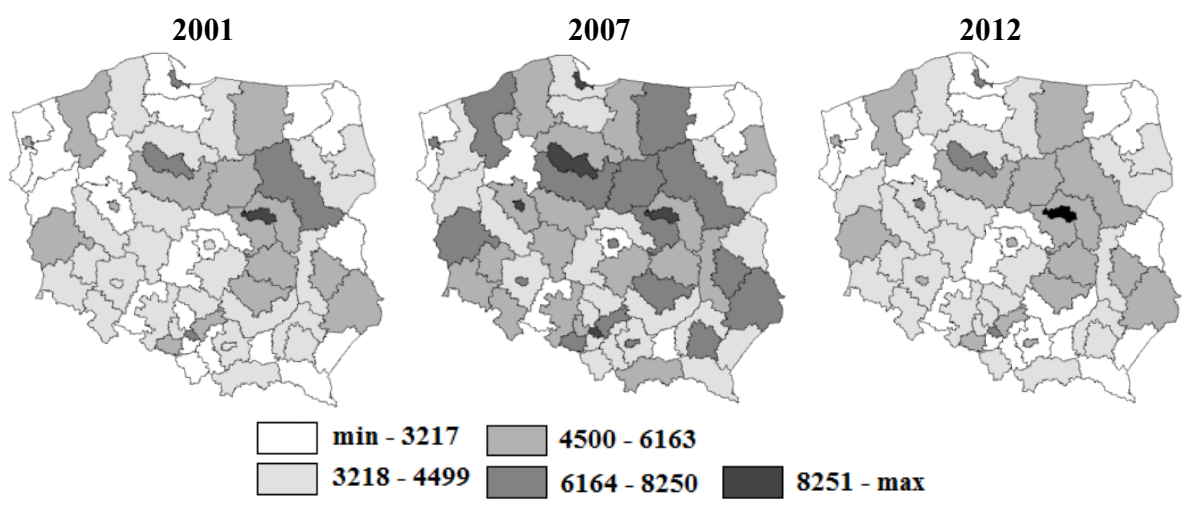

Figure 3. Spatial differentiation of overall population outflow (number of individuals) according to subregions in Poland in 2001, 2007 and 2012

Source: authors' elaboration

The level of emigration in Poland is characterized by quite considerable spatial differentiation. The maps clearly show that, in all the periods, the highest number of deregistrations was noted in the eastern part of the country - in subregions situated in the Mazowieckie, Lubelskie and Świętokrzyskie voivodeships. In turn, the lowest number was observed in the subregions of Łódzkie, Zachodniopomorskie, Małopolskie and Podkarpackie voivodeships (the characteristic feature of the Lódzkie voivodeship, and in particular, the Skierniewickie and Łódzkie subregions, is the shuttle movement of the population connected with commuting to Warsaw - hence, the low level of population outflow from that area). In 2007 and 2012, the phenomenon of population outflow from the big cities, i.e. Warsaw, Poznań, Cracow, Łódź, Wrocław, Gdańsk, intensified. In those cities, however, we generally observed more intense population movements, both outflow and inflow-associated, compared to other areas.

Figure 4 shows that females are more willing to move within the country. The biggest difference between the outflow of females and males in 2001, 2007 and 2012 was noted in the Ostrołęcko-Siedlecki subregion (the Mazowieckie voivodeship) - differences of 574, 1014 and 1013 individuals, respectively. 

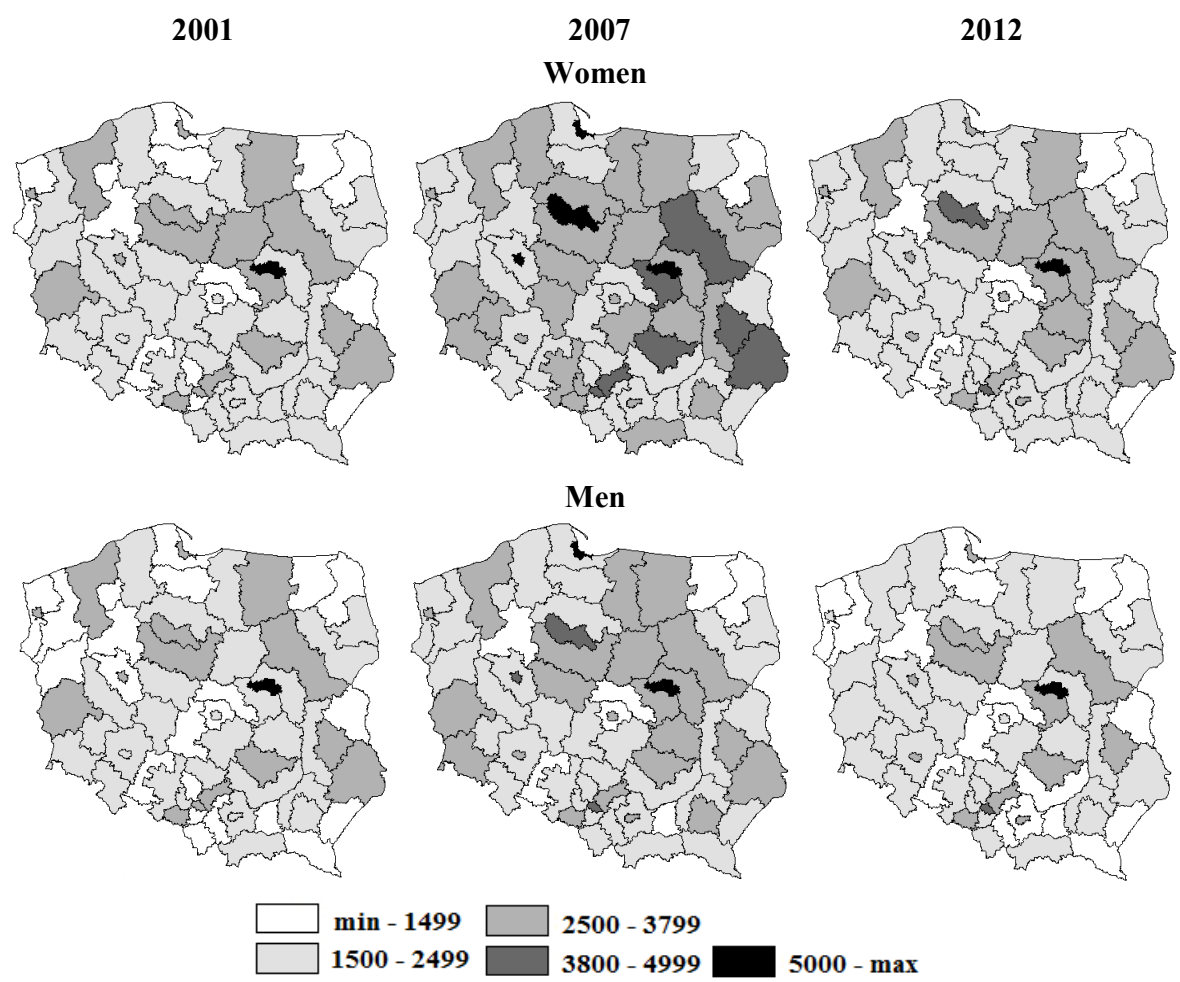

2500 - 3799

$3800-4999 \square 5000-\max$

Figure 4. Spatial differentiation of overall emigration level of females and males (number of individuals) according to subregions in Poland in 2001, 2007 and 2012

Source: authors' elaboration

The predominance of males (of 67 individuals) was observed solely in the city of Szczecin subregion in 2001(Figure 4). In the whole studied period,the biggest number of females emigrated in 2007 from the following subregions: the city of Warsaw (over 8,000 individuals), Trójmiejski, the city of Poznań, Bydgosko-Toruński, Katowicki, Ostrołęcko-Siedlecki, Warszawsko-Zachodni and Lubelski. In turn, the lowest number emigrated in 2001 from the Lódzki, Ełcki, Nyski and Starogardzki subregions.

Figure 5 shows the clear difference between the levels of population outflow to urban and rural areas. The biggest number of individuals emigrated to another urban area or from a rural to a rural area in 2007, in particular from the city of Warsaw, the Katowicki and Trójmiejski subregions. As for population outflow to rural areas, this was the largest in the city of Warsaw, the city of Poznań and the Bydgosko-Toruński subregions, also in 2007. 
2001
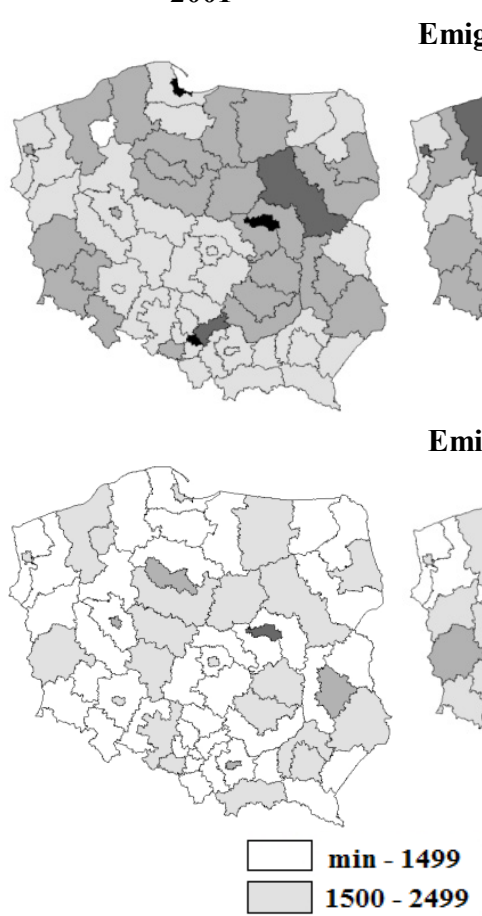

2007

\section{Emigration to urban areas}

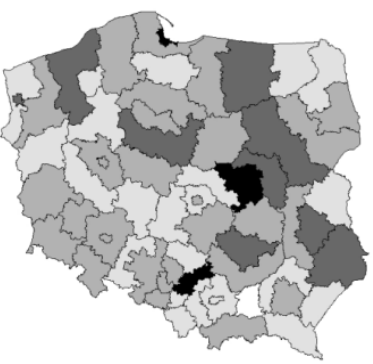

Emigration to ruralareas

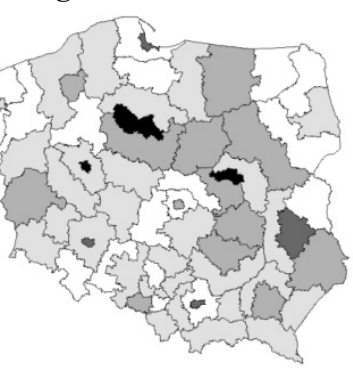

2500 - 3799

$3800-4999$
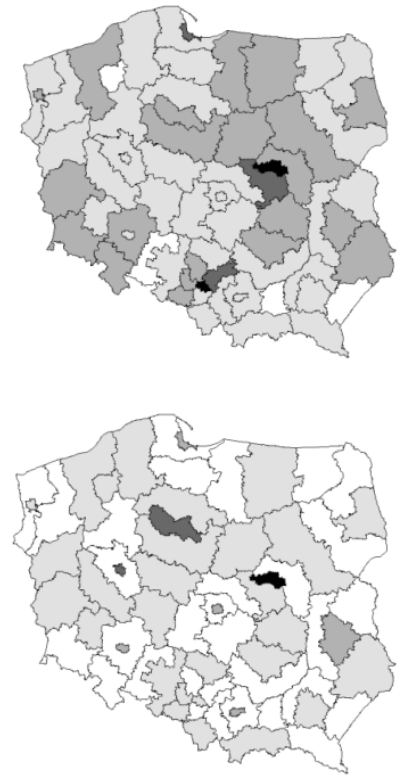

$5000-\max$

Figure 5. Spatial differentiation of the overall emigration level to urban and rural areas (number of individuals) according to subregions in Poland in 2001, 2007 and 2012

Source: authors' elaboration

Additionally, the map shows the increased number of individuals moving to rural areas from big cities, i.e. Warsaw, Poznań, Cracow, Wrocław and Łódź in 2007 and 2012, which is consistent with the current trend to improve the standard of living by the rich.

\section{THE SHIFT-SHARE METHOD}

\subsection{Classical static and dynamic (recursive) shift-share}

The structural and geographic shift-share analysis allows to assess the development level of the studied phenomenon in a selected region compared to the development level of that phenomenon in an area assumed to be the reference one. Relative changes in the size of the phenomenon (i.e. rates or 
pace of changes) are divided into regional (geographic, spatial), crosssectional (structural) and global (domestic) factors in relation to one or more features. The net effects are a relative change in a region reduced by constant global change. In turn, the global net effect enables the selection of structural and spatial effects. In the traditional shift-share approach,the net change is calculated as follows:

$$
t x_{r \bullet}-t x_{\bullet \bullet}=\sum_{i} w_{r \bullet(i)}\left(t x_{\bullet i}-t x_{\bullet \bullet}\right)+\sum_{i} w_{r \bullet(i)}\left(t x_{r i}-t x_{\bullet i}\right)
$$

where: $t x_{r \bullet}-$ pace of changes in the phenomenon level in the current period compared to the base period in the $r$ th region, $t x_{. .}-$global effect, $w_{r \cdot(i)}-$ regional weights for the $r$ th region, $t x_{r_{\bullet}}-t x_{. \bullet}-$ total/net regional effect, $\left(t x_{\bullet i}-t x_{. .}\right)-$structural factor of regional growth, $\left(t x_{r i}-t x_{\bullet_{i}}\right)-$ local (geographic, competitive, differentiating) growth factor in the $i$ th sector of the $r$-th -region.

The first element of the sum (of the net effect) is the structural effect and the other - the geographic effect. Equation (1) can be written as follows:

$$
\text { Net Effect }=\text { Structural Effect }+ \text { Geographical Effect }
$$

The presented method was proposed at the turn of the 1950s (Creamer, 1942), and popularized in research on the differentiation of regional economic growth in the 1960s (Dunn, 1960). The feature and, at the same time, the weakness of the static approach is the assumption of constant changes of the analysed phenomenon over time. Distribution is applied to changes in values from the initial to final period (or from the final to initial period). If a change in the value over several years is studied, it is justified to assume that the value of the analysed feature changes over time. In the late 1980s, Barff and Knight (1988) proposed to dynamize the traditional approach to shift-share analysis, i.e. to assume changing weights and perform recursive calculations. Then, (relative, absolute or net) changes in the value of the studied feature and specific effects are determined sequentially for each pair of consecutive periods.

\subsection{Spatial shift-share}

Although the traditional and dynamic approaches to shift-share analysis take into consideration the geographic aspect of changes in the value of the studied variable, they do not assimilate the idea of spatial relationships 
among regions. Thus, studied objects are regarded as economically and geographically unconnected. In 2004, Nazara and Hewings proposed to introduce elements of a spatial weights matrix to the classical structural and geographic equation, described by formula $(1)^{3}$. Thus, along with the ordinary weights of traditional and recursive approaches, the weights of spatial interactions among regions were also taken into account. The factor of spatial relationships is included in the structural or geographic effect or in both at the same time (Suchecki, Antczak 2010).

In the case of the dynamization of the spatial shift-share method, the analysis proposed by Nazara and Hewings has to be repeated for each pair of consecutive periods, and changes and effects have to be summed up (Antczak, Żółtaszek, 2010). Spatial weights do or do not change over time. Therefore, the compilation of the spatial and dynamic approaches indicates that the pace of changes in the analysed variable, and thus the structural and geographic effects and elements of the spatial weights matrix (spatial interactions, relationships), change from one period to the next rather than only from the final moment of analysis to the initial one ${ }^{4}$.

\subsection{Application of Shift-Share Methods in Migration Analyses}

A traditional static shift-share approach to migration analyses was adopted for the first time by Plane (1987). He analysed the geographic factors determining the change in the structure of interregional migration flows in the United States in the 1980s. In 1989, an article was published in which Plane and Rogerson continued the analysis concerning structural changes in individuals migrating in selected US regions. The issue of interregional migrations (this time in Japan) in the context of migrants' numbers, employing the described method, was raised by Ikishawa (1992). In the same year, the results of Plane's research were also published regarding the age structure of migrants in the United States. The traditional approach of the static shift-share method in research on the phenomenon of migration was implemented, among others, by Wright and Ellis (1997), Perry and Hayward (2003), and Franklin (2012). The dynamic shift-share method was also first employed in research on migration by Plane (1989). Then, Plane and Rogerson (1994) performed an analysis concerning the geographic determinants of the demographic processes using the

\footnotetext{
${ }^{3}$ The first law of geography according to Waldo Tobler (1970), is: "Everything is related to everything else, but near things are more related than distant things". Spatialdependenciesare included in elements of spatial matrixes.

${ }^{4}$ Other modifications of these method are presented by Suchecki et al. (2010).
} 
described tool. The method was also applied in empirical research on migration by, among others, Ishikawa (1999), Franklin and Plane (2004), and Franklin (2012).

A compilation of the spatial shift-share method, stochastic models and panel models in migration analysis was attempted, among others, by Sweeney and Goldstein (2005), Chen, Xu (2006), D'Amurii and Peri (2010), Etzo (2011) and Franklin (2012).

In Poland, the spatial shift-share method was used, among others, in studies concerning remunerations, by Antczak, Żóltaszek (2010) ${ }^{5}$, and economics and healthcare, by Jewczak, Żółtaszek (2011). No results of studies on migration conducted using the method presented in that part of the paper have been published so far.

\section{RESULTS OF ANALYSIS}

The analysis concerned the relative changes (pace of changes) in the number of emigrants (to urban and rural areas, separately for males and females) in subregions of Poland from 2000 to 2012. The base period was always the previous year. Regional weights $\left(u_{r \bullet(i)}\right)$ were defined as the share of the number of emigrants depending on the type of deregistration in a given subregion in the total volume of emigration of that spatial unit. The reference variable was assumed to be the overall number of emigrants (deregistrations) in Poland. The analysis was carried out for every two periods separately. Afterwards, the received study results were summed up. The applied spatial recursive shift-share model also considered a spatial weights matrix determined based on a binary sixth-rank adjacency matrix $\mathbf{W}$ standardized in rows to one, whose elements reflect occurring interregional interactions ${ }^{6}$ :

$$
\mathbf{W} t x_{i}=\frac{\left(\sum_{k=1}^{R} w_{r k} x_{k i}^{*}-\sum_{k=1}^{R} w_{r k} x_{k i}\right)}{\sum_{k=1}^{R} w_{r k} x_{k i}}, i=1, \ldots, M,
$$

where: W - symmetrical spatial weights matrix constructed based on the direct adjacency of subregions of the sixth rank (considering also adjacent

\footnotetext{
${ }^{5}$ In the publication one could find the comparison of results achieved by using shift-share techniques (traditional, dynamic, spatial and spatial dynamic).

${ }^{6}$ More in: Anselin (1988).
} 
objects of lower ranks); $i$ - emigrant category (direction of deregistration for each gender separately); $r$ and $k$ - subregion numbers for $r, k=1, \ldots, R$; $x_{k i}$ - volume of emigration in the $k$ th subregion for the $i$ th deregistration category; $x_{k i}^{*}$ - analogous value for the final period (assuming recursiveness); $w_{r k}$ - element of the spatial weights matrix for the $r$ th and $k$ th subregions.

The used model, taking into account recursiveness and interregional relationships, was described with the following formula:

$$
\sum_{s}\left(t x_{r \bullet}-t x_{\bullet \bullet}\right)=\sum_{s} \sum_{i} u_{r \bullet(i)}\left(\mathbf{W} t x_{i}-t x_{\bullet \bullet}\right)+\sum_{s} \sum_{i} u_{r \bullet(i)}\left(t x_{r i}-\mathbf{W} t x_{i}\right),
$$

where: $t x_{r \bullet}-$ pace of changes in the number of emigrants (deregistrations) in the current $s$-th period as compared to the base $s$-th period, i.e. the period preceding the current one, in the $r$ th subregion; $t x_{\text {.. }}-$ global pace of changes in the reference variable (total number of emigrants in Poland); $u_{r \bullet(i)}$ - regional weights for the $r$ th subregion in the form of shares of the analysed variable in the total value of that variable for a given subregion; $\left(t x_{r \bullet}-t x_{\bullet .}\right)-$ global regional effect (net effect); $\left(\mathbf{W} t x_{\bullet i}-t x_{. .}\right)-$structural regional growth factor (here for the direction of migration- deregistration category for males and females separately); $\left(t x_{r i}-\mathbf{W} t x_{\bullet_{i}}\right)-$ local (geographic, competitive, differentiating) growth factor in the $i$ th migration category (sector) of the $r$ th subregion.

The values of the computed effects for changes in the volume of emigration from 2000 to 2012, characterizing the specific subregions according to four deregistration categories, are shown in Figure 6.

The data provided in Figure 6 indicate that the 2000-2012 mean pace of changes in the volume of population outflow in the subregions (overall without specifying deregistration categories) is $+3.6 \%$. That implies an increase of over 3\% in the number of males and females emigrating to urban and rural areas in 2012 compared to 2000 (taking into account the changes in the phenomenon in the specific analysed years: from 2001 to 2011).

The highest positive regional mean pace of changes in the described phenomenon (from $15 \%$ to $43.4 \%$ ) characterizes the following cities: Wrocław (43.4\%), Poznań (34.7\%), Cracow (30.8\%), Szczecin (20.6\%), Łódź (20.3\%), Warsaw (18.2\%) and the subregions: Bytomski (19.2\%), Rzeszowski (18.4\%), Bydgosko-Toruński (17.6\%), Bielski (16.4\%), Poznański (16.3\%), Gdański (15.6\%), Gliwicki (15.3\%) and Warszawski 


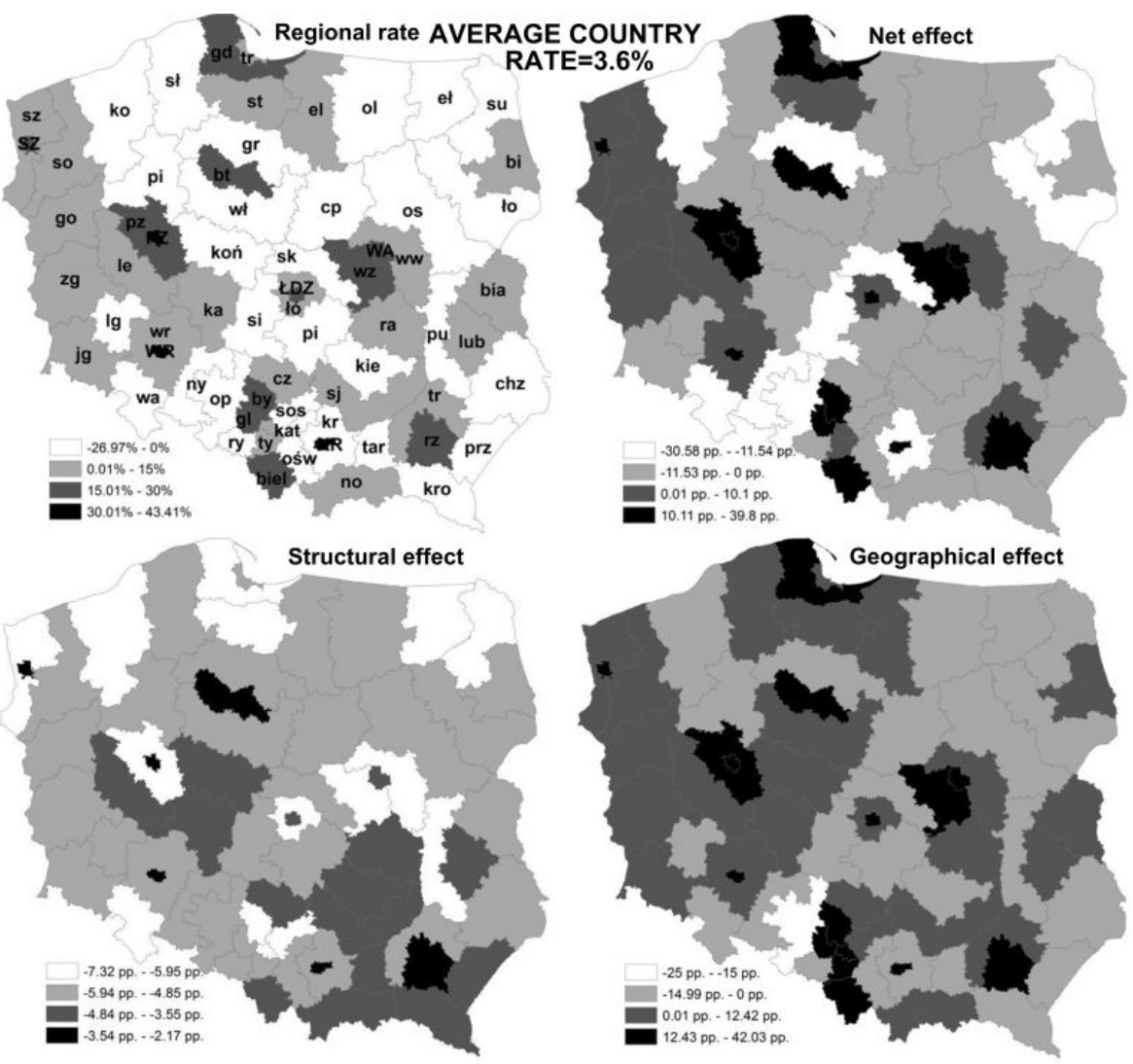

Note: bia-bialski, bi-białostocki, biel-bielski, bt-bydgosko-toruński, by-bytomski, chzchełmsko-zamojski, cp- ciechanowsko-płocki, cz-częstochowski, el-elbląski, eł-ełcki, gdgdański, gl-gliwicki, go-gorzowski, gr-grudziądzki, jg-jeleniogórski, ka-kaliski, katkatowicki, kie-kielecki, ko-koszaliński, koń-koniński, kr-krakowski, KR-Kraków, krokrośnieński, le-leszczyński, lg-legnicko-głogowski, lub-lubelski, ŁDZ-Łódź, ło-łomżyński, łó-łódzki, no-nowosądecki, ny-nyski, ol-olsztyński, op-opolski, os-ostrołecko-siedlecki, ośwoświęcimski, pi-pilski, pio-piotrkowski, prz-przemyski, pu-puławski, PZ-Poznań, pzpoznański, ra-radomski, ry-rybnicki, rz-rzeszowski, si-sieradzki, sj-sandomiersko-jędrzejski, sk-skierniewicki，sł-słupecki， sos-sosnowiecki，so-stargardzki，st-starogardzki， su-suwalski, SZ-Szczecin, sz-szczeciński， tar-tarnowski， tb-tarnobrzeski， trj-trójmiejski， ty-tyski，wawałbrzyski, WA-Warszawa, wł-włocławski, WR-Wrocław, wr-wrocławski, ww-warszawaski wschodni, wz-warszawaski zachodni, zg-zielonogórski.

Figure 6. Results of the spatial structural-geographic analysis of changes in emigration volume according to subregions

Source: authors' elaboration 
Zachodni (15.3\%). In the above-mentioned subregions there was the highest increase in the number of emigrants in 2012 compared to 2000. For example, in Wrocław, the level of emigration rose by $43 \%$ on average in the analysed period, while the pace of the phenomenon was by about $40 \mathrm{pp}$ faster than the mean domestic pace (net effect: $39.8 \mathrm{pp}$ ). The mean increase in the number of deregistrations in Łódź was over $20 \%$ (i.e. a pace faster by about $17 \mathrm{pp}$ than in Poland), whereas, for instance, in the Bytomski subregion, the increase in the emigration volume was $19.2 \%$ with the net effect of $15.6 \mathrm{pp}$.

The largest decreases in the number of emigrants were noted in the Opolski (-27\%), Wałbrzyski (-17.3\%), Sieradzki (-13\%), Łomżyński ($12.5 \%)$, Krakowski (-12.3\%) and Nyski (-12.1\%) subregions. In 2012, compared to 2000, the largest drop in the number of deregistrations occurred in the Opolski subregion, where the pace of changes in emigration was slower by over $30 \mathrm{pp}$ than the mean pace in Poland (net effect: -30.6 pp,Figure 6).

The analysis results (Figure 6) indicate that changes in emigration volume in specific subregions resulted either from changes in the deregistration structure of females and males according to specific directions (structural effects) or from local competitiveness (geographic effects). The values of the received results were also affected by the character of the assumed spatial weights matrix. In the case of the described phenomenon (as a destimulant of development), the positive value of the geographic effect reflects the excessive outflow of individuals from a given unit to adjacent regions, i.e. the uncompetitiveness of a given region, according to the assumed spatial weights matrix. On the other hand, the negative values of that effect characterize units where the number of emigrants is lower on average, i.e. they are competitive when compared to the other studied units, according to the assumed matrix W. For example, from 2000 to 2012, Wrocław's value of the net effect of $39.8 \mathrm{pp}$ was mainly influenced by local "competitiveness" (geographic effect: $42 \mathrm{pp}$, structural effect: $-2.23 \mathrm{pp}$ ) resulting from interregional connections, adjacency to other units or transportation availability. A similar situation also occurred, for instance, in Poznań (geographic effect: $33.6 \mathrm{pp}$, structural effect: $-2.5 \mathrm{pp}$ ), Cracow (geographic effect: $29.3 \mathrm{pp}$, structural effect: $-2.2 \mathrm{pp}$ ), Łódź (geographic effect: 20.5 pp, structural effect: -3.8 pp), Szczecin (geographic effect: 19.9 $\mathrm{pp}$, structural effect: $-2.9 \mathrm{pp}$ ), Warsaw (geographic effect: $18.6 \mathrm{pp}$, structural effect: $-2.9 \mathrm{pp}$ ), the Rzeszowski subregion (geographic effect: $17.5 \mathrm{pp}$, 
structural effect: $-2.8 \mathrm{pp}$ ), the Bytomski subregion (geographic effect: 21.9 $\mathrm{pp}$, structural effect: $-6.3 \mathrm{pp}$ ) and many more. On the other hand, in the Nyski subregion, where the domestic pace of changes is negative $(-12 \%)$ and the changes are slower than the pace of changes in the reference area by $15.6 \mathrm{pp}$ (net effect: $-15.6 \mathrm{pp}$ ), the value of the global effect is more affected by the negative value of the geographic effect $(-10.3 \mathrm{pp})$ than by structural effects $(-5.4 \mathrm{pp})$. Such a situation reflects the smaller scale of migration from that subregion to other parts of Poland (i.e. the competitiveness of that subregion compared to other parts, according to the assumed spatial weights matrix). A similar situation arises for ten other subregions, accounting for $15 \%$ of all the analysed units.

In a considerable number of subregions ( 28 units, which represents $42 \%$ of all subregions), the value of the net effect is more influenced by changes in emigrants' structure, with a lower value of the geographic effect (Figure 6). What is typical of these subregions is the slower pace of the number of deregistrations compared to that in Poland (negative net effects). Such a situation occurs, for instance, in the Kaliski (net effect: -0.4 pp), Opolski (net effect: $-0.5 \mathrm{pp}$ ) and Białostocki (net effect: $-0.1 \mathrm{pp}$ ) subregions. In all these subregions, however, the negative value of the net effect was affected by the negative value of the structural effect (the Kaliski subregion's structural effect: $-4.3 \mathrm{pp}$, geographic effect: $3.9 \mathrm{pp}$; the Opolski subregion's structural effect: $-3.9 \mathrm{pp}$, geographic effect: $3.4 \mathrm{pp}$; the Białostocki subregion's structural effect: $-5.3 \mathrm{pp}$, geographic effect: 5.2 $\mathrm{pp}$ ). Thisamounts to slower changes in the structure of emigrants in these areas than in Poland. Among the subregions, there were those where an increase in the volume of emigration occurred in the analysed period (positive regional pace), e.g. in the Białostocki, Opolski and Kaliski subregions, but the majority of units (twenty) showed a decrease in the number of migrants.

The data contained in Table 1 indicate that the value of the net effect of emigration volume in specific subregions from 2000 to 2012 can be significantly affected by the local geographic effect (arising from "competitiveness", the impact of units' adjacency, spatial relationships). This change couldalso be due to the structural effect (pace of changes in the structure of deregistrations of males and females due to departure to urban or rural areas). On the other hand, the values of the structural and geographic effects are influenced by the share of the volume of changes in a specific deregistration type - emigrant "category" (Table 1). 
Table 1

Share of the volume of changes in specific emigrant groups in values of global, structural and geographic effects of selected subregions (data in percentages and percentage points)

\begin{tabular}{|c|c|c|c|c|c|c|c|c|c|c|c|c|}
\hline & \multirow{2}{*}{$\begin{array}{c}\text { RR } \\
\text { in \% }\end{array}$} & $\mathbf{N E}$ & MCI & WCI & MCT & WCT & SE & MCI & WCI & MCT & WCT & GE \\
\hline & & \multicolumn{11}{|c|}{ In percentagepoints } \\
\hline $\mathrm{gd}$ & 15.6 & 12 & -4 & -3.34 & -0.2 & 0.65 & -6.88 & 5.48 & 5.97 & 2.74 & 4.68 & 18.88 \\
\hline $\mathrm{SZ}$ & 20.6 & 16.98 & -2.58 & -1.91 & -0.04 & 1.56 & -2.97 & 1.82 & -0.67 & 9.13 & 9.67 & 19.95 \\
\hline to & -12.5 & -16.08 & -3.7 & -3.06 & -0.01 & 1.02 & -5.75 & -5.41 & -4.26 & -0.04 & -0.63 & -10.33 \\
\hline $\mathrm{PZ}$ & 34.7 & 31.09 & -2.35 & -1.73 & 0.05 & 1.57 & -2.47 & -0.03 & -0.84 & 17.15 & 17.28 & 33.56 \\
\hline WA & 18.2 & 14.58 & -3.18 & -2.22 & 0.10 & 1.31 & -3.99 & 3.77 & 3.32 & 6.23 & 5.25 & 18.58 \\
\hline $\mathrm{wz}$ & 15.3 & 11.66 & -3.84 & -3.18 & -0.04 & 0.75 & -6.31 & 6.37 & 7.47 & 1.84 & 2.29 & 17.97 \\
\hline$€ D Z$ & 20.3 & 16.68 & -2.86 & -2.27 & -0.03 & 1.38 & -3.78 & 2.53 & 3.91 & 6.89 & 7.14 & 20.46 \\
\hline WR & 43.4 & 39.8 & -2.34 & -1.7 & 0.10 & 1.7 & -2.23 & 2.32 & 3.79 & 18.27 & 17.65 & 42.03 \\
\hline op & $3.1 \%$ & -0.5 & -3.1 & -2.2 & 0.1 & 1.3 & -3.9 & 0.5 & 2.2 & 0.3 & 0.3 & 3.4 \\
\hline kat & 11.8 & 8.16 & -4.59 & -3.37 & 0.04 & 0.61 & -7.32 & 7.42 & 5 & 1.47 & 1.59 & 15.48 \\
\hline $\mathrm{kr}$ & -12.3 & -15.93 & -3.47 & -2.83 & 0.01 & 1.04 & -5.25 & -3.97 & -3.04 & -2.74 & -0.93 & -10.68 \\
\hline KR & 30.8 & 27.16 & -2.25 & -1.62 & 0.003 & 1.7 & -2.17 & 4.34 & 3.26 & 12.39 & 9.34 & 29.33 \\
\hline $\mathrm{rz}$ & 18.4 & 14.75 & -2.8 & -1.95 & 0.4 & 1.6 & -2.75 & 13.6 & 11.52 & -3.47 & -4.16 & 17.49 \\
\hline
\end{tabular}

Average country (Polish) rate: $3.6 \%$

Note: RR- regional rate, $\mathrm{MCI}$ - men migrating to cities, WCI-women migrating to cities, MCT - men migrating in countries, WCT- women migrating in countries, NE - net effect, SE - structural effect, GE - geographical effect.

Source: authors' elaboration

The data contained in Table 1 indicate that the value of the net effect, e.g. in Wrockaw (where the fastest positive pace of changes in the volume of emigration was observed), was mainly affected by the value of the geographic effect (42 pp), which, in turn, resulted from the fastest pace of increase in the number of males migrating to urban areas (18.27 pp). That implies that it was males migrating to urban areas of adjacent regions (according to the assumed spatial weights matrix) that constituted the largest group of individuals in that subregion. Thus, the emigration pace of that category of individuals was significantly faster than in other groups in that area. A similar trend emerges in other selected subregions, e.g. in Warsaw or Cracow (Table 1). On the other hand, in Łódź, Poznań and Szczecin, the largest share in the geographic effect was that of the faster pace of increase in the number of females migrating to rural areas (in adjacent subregions according to the assumed space weights matrix) than in the other groups of emigrants.

In turn, in subregions showing a decrease in the volume of the phenomenon, and thus a pace of emigration slower than Poland's pace of 
changes, the geographic effect is negative and has a major impact on the value of the net effect. For example, in the Krakowski subregion the value of the geographic effect (-10.68 pp), i.e. the unit's competitiveness, was mainly affected by the slower pace of changes in emigration volume in the group of males $(-3.97 \mathrm{pp})$ and females (-3.04 pp) to urban areas (according to the assumed weights matrix) than in other migrant groups.

A selected example of a unit where the regional pace of emigration lower than that of Poland and the negative net effect were most significantly affected by changes in the structure of deregistrations is the Opolski subregion (net effect: $-0.5 \mathrm{pp}$, structural effect: $-3.9 \mathrm{pp}$, geographic effect: $3.4 \mathrm{pp}$ ). In turn, the volume of the structural effect was mainly influenced by the pace of changes in the number of males migrating to urban areas (-3.1 pp). Therefore. in the Opolski subregion, there were slower changes in the number of deregistrations in that group of individuals in the studied period (negative value). What is more, the share of that pace in the value of the structural effect was the biggest when compared to changes in the phenomenon's volume in other emigrant groups in that subregion (Table 1).

Changes in the emigration level, determined based on structural-geographic equation (4), indicated that every subregion shows a certain specificity (arising, for instance, from the economic-social-spatial conditions typical of a given unit). Furthermore, the net effect values are also affected by volumes of the sectoral pace of changes and the sectoral net effect (Figure 7).

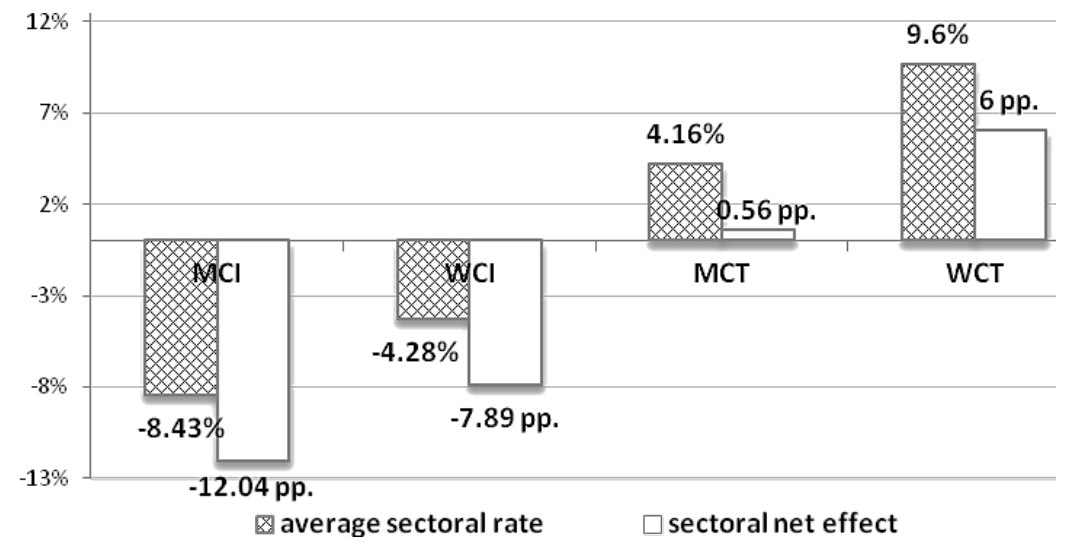

Figure 7. Sectoral effects of migration according to the specific structure of emigrants (in percentages and percentage points)

Source: authors' elaboration. 
Results shown in Figure 7 prove that the fastest positive pace of changes in the number of deregistrations (i.e. emigrants) characterized the females migrating to rural areas $(9.6 \%)$ from 2000 to 2012. In that category of individuals, the pace of emigration was faster than the mean pace of changes in Poland by $6 \mathrm{pp}$. The slowest changes in the number of emigrants occurred in the category of males migrating to urban areas (sectoral effect: $-8.43 \%$, sectoral net effect: $-12.04 \mathrm{pp}$ ). Moreover, the analysis results indicate the largest increase in the volume of migration to rural areas in the group of females $(9.6 \%)$, a smaller increase in the group of males $(4.16 \%)$, the largest decrease in the emigration volume in the group of males migrating to urban areas $(-8.43 \%)$ and a slower decrease in the group of females $(-4.28 \%)$.

\section{SUMMARY}

Internal population flows are a very complex phenomenon depending on many familial, social, environmental, cultural, economic aspects etc. They have a multitude of both positive and negative consequences for the individual, family, local community and thus, for the whole country. Therefore, this phenomenon should be constantly monitored and thoroughly analysed.

The article attempted to analyse the level of internal emigration in Poland (population outflow to other subregions) according to the gender and migration direction (urban, rural) criteria from 2000 to 2012.

The results of the carried-out analysis indicate an increase in the mean emigration volume (expressed as the number of deregistrations due to departure to urban and rural areas) in Poland's subregions from 2000 to 2012 (mean domestic pace: 3.6\%). However, the volume of the changes was affected by both the specificity of the studied subregions (to be identified in further studies) and the ambiguous changes occurring in specific migrant groups (depending on the direction of migration and the migrants' gender). The fastest positive pace of changes in the number of deregistrations (i.e. emigrants) characterized females migrating to rural areas $(9.6 \%)$. The slowest changes in the number of emigrants occurred in the category of males migrating to urban areas (slower by $12.04 \mathrm{pp}$ than the mean pace in Poland).

The fastest positive pace of changes in the emigration volume in the studied period was noted mainly in cities, e.g. Wrocław, Poznań, Cracow, Szczecin, Łódź, Warsaw, and the Bytomski, Rzeszowski or Bydgosko-Toruński subregions. On the other hand, a decrease in directional migration volume occurred in the Wałbrzyski and Sandomiersko-Jędrzejowski subregions. 
From 2000 to 2012, a mean increase in emigration volume (positive mean paces of changes) was observed in thirty-seven subregions (accounting for $56 \%$ of all units), of which twenty-eight subregions (more than $42 \%$ of all units) showed the pace of the phenomenon to be faster than the mean emigration pace in Poland. What is more, twenty-nine subregions $(44 \%$ of all) were characterized by a decrease in the directional migration volume of males and females (negative values of regional paces). In turn, thirty-eight units (58\% of all subregions) showed an emigration pace slower than the mean in Poland (negative values of net effects). In subregions where the value of the geographic effect is positive and has a bigger share in the value of the structural effect ( $42 \%$ of all subregions), an adverse trend can be observed of excessive population outflow to other, possibly more attractive subregions of Poland. In $15 \%$ of subregions the value of the global effect is more influenced by the negative value of the geographic effect than the values of structural effects. Thus, such units are characterized by a smaller scale of migration from a given subregion to other units ( such a situation reflects the competitiveness of that subregion compared to the other units, according to the assumed spatial weights matrix). However, in a considerable number of subregions (28 units, which represents $42 \%$ of all subregions), the value of the net effect is more influenced by changes in emigrants' structure, with a lower value of the geographic effect. What is typical of these regions is the slower pace of the number of deregistrations compared to that in Poland (negative net effects).

The changes in emigration volumes in the presented deregistration categories are reflected by the level of sectoral effects as well as the volumes of global, structural and geographic effects.

To sum up, the conducted analysis enabled the allocation of changes in the studied phenomenon to the specified components, and thus provided additional information indicating that the observed changes are regionally characterized by a certain developmental trend which, however, is specific for each region. Nevertheless, due to the generality of statistical information, the received results should be regarded as a starting point for further, more detailed study taking into account cause and effect relationships. Thus, the subsequent step in research will be to specify both the economic and noneconomic variables affecting internal migration in Poland. Due to the fact that population movements may also be influenced by spatial aspects, i.e. geographic location, adjacency and distance, advanced spatial econometrics tools will be used in further analyses, i.e. spatial panel models or multiequation spatial regression models. 


\section{REFERENCES}

Anselin, L., Spatial Econometrics: Methods and Models. Kluwer Academic Publishers, Dordrecht, 1988.

Antczak, E., Żółtaszek, A., Przestrzenno-czasowe analizy zróżnicowania wynagrodzeń w Polsce [Spatial and Temporal Effects of Wage Diversification in Poland], [in:] Pociecha, J. (ed.), Aktualne zagadnienia modelowania $i$ prognozowania zjawisk społecznogospodarczych [Recent Problems in Modelling and Forecasting of Social and Economic Phenomenena], Studia i prace Uniwersytetu Ekonomicznego w Krakowie, Wydawnictwo Uniwersytetu Ekonomicznego w Krakowie, pp. 283-298, 2010.

Barff, R. A., Knight, P.L., Dynamic Shift-Share Analysis, "Growth and Change” 19, pp. 1-10, 1988.

Chen, W., Xu, J., An Application of Shift-Share Model to Economic Analysis of County, England, "UK World Journal of Modelling and Simulation", Vol. 3 (2007) No. 2, pp. 9099, 2007.

Creamer, D., Shift of Manufacturing Industries, Industrial Location and National Resources. Washington D.C: U.S. Government Printing Office, 1942.

D’Amuri, F., Peri, G., Immigration and Occupations in Europe, Centro Studi Luca D'Agliano Development Studies Working Papers N. 302, 2010.

Dunn, E. S., A Statistical and Analytical Technique for Regional Analysis, "Papers of the Regional Science Association", Vol.6, pp. 97-112, 1960.

Etzo, I., The Determinants of the Recent Interregional Migration Flows in Italy: A Panel Data Analysis, "Journal of Regional Science", Vol. 51, No. 5, pp. 948-966, 2011.

European Urban Knowledge Network, Immigrant Integration in European Cities, http://www.eukn.org/Dossiers/EU_presidencies/Cyprus_Presidency/Immigrant_integratio n_in_European_Cities, 2012 (accessed on: 20.02.2015).

Franklin, R., An Examination of the Geography of Population Composition and Change in the United States, 2000-2010, Insights from Geographical Indices and a Shift-Share Analysis Spatial Structures in the, Population, Space And Place Article first published online: 8 NOV 2012 DOI: 10.1002/psp.1744 Popul. Space Place Published online in Wiley Online Library (wileyonlinelibrary.com) DOI: 10.1002/psp.1744, 2012.

Franklin, R., Plane, D. A, A Shift-Share Method for the Analysis of Regional Fertility Change: An Application to the Decline in Childbearing in Italy 1952-1991, "Geographical Analysis", Vol. 36, No. 1, 2004.

International Organization for Migration, Internal Migration and Development. A Global Perspective, Migration Research Series, No. 19, 2005.

Ishikawa, Y., The 1970s Migration Turnaround in Japan Revisited: A Shift Share Approach, "Papers in Regional Science" 71, pp. 153-173, 1992.

Jewczak, M., Żółtaszek, A., Spatial Shift-share Analysis as a Health Policy Tool, Acta Universitatis Lodziensis, "Folia Oeconomica",No. 252, pp. 87-100, 2011.

Kaczmarczyk, P., Tyrowicz, J., Współczesne procesy migracyjne w Polsce, a aktywność organizacji pozarzadowych w obszarach powiazanych z rynkiem pracy[Current Migration Processes in Poland and Activity of Non-governmental Organizations in the Areas Related to Labour Market], FISE, Warszawa, 2007. 
Kałuża-Kopias, D., Migracje wewnętrzne w Lodzi na tle wybranych, największych miast $w$ Polsce[Internal Migrations in Lodz against Selected Biggest Cities in Poland], „Folia Sociologica" 35, Wydawnictwo Uniwersytetu Łódzkiego, Łódź, 2010.

Migracje zarobkowe i powrotne w Polsce oraz w województwie warmińsko-mazurskim [Economic and temporary migrations in Poland and in the Warmian-Masurian Voivodeship](2009), Raport z projektu pt. Powrót do domu - psychospołeczne mechanizmy adaptacyjne migrantów powrotnych $\mathrm{z}$ terenów województwa warmińsko-mazurskiego, współfinansowanego przez Unię Europejską w ramach Europejskiego Funduszu Społecznego, http://www.up.gov.pl/uploads/media/2._Migracje_zarobkowe_i_powrotne_raport_ekspercki. $\operatorname{pdf}(12.09 .2013 \mathrm{r}$.).

Nazara, S., Hewings, G. J. D., Spatial Structure and Taxonomy of Decomposition in ShiftShare Analysis, "Growth and Change" 35 (4), pp. 476-90, 2004.

Perry, M., Hayward, D., Contribution of Demographic Structure to Regional Migration, 1991-2001, "New Zealand Population Review" 29(2), pp. 139-146, 2003.

Plane, D. A., The Geographic Components of Change in a Migration System, "Geographical Analysis" 19, pp. 283-299, 1987.

Plane, D. A., Rogerson, P. A., The Geographical Analysis of Population with Applications to Planning and Business. John Wiley\& Sons, Inc, New York, 1994.

Plane, D. A., Population Migration and Economic Restructuring in the United States, "International Regional Science Review" 12, pp. 263-280, 1989.

Plane, D. A., Rogerson, P., U.S Migration Pattern Responses to the Oil Glut and Recession of the Early 1980s: An Application of Shift-share and Causative Matrix Techniques, Advances in Regional Demography. Belhaven press, London, 1989.

Plane, D., Age-Composition Change and the Geographical Dynamics of Interregional Migration in the US, "Annals of the Association of American Geographers" 82 (1), pp. 64-85, 1992.

Sasin, M., Główne determinanty migracji statych $w$ Polsce $w$ latach 2003-2008 [Main Determinants of Permanent Migrations in Poland between 2003 and 2008], „Folia Oeconomica" 253, Wydawnictwo Uniwersytetu Łódzkiego, Łódź, 2011.

Stelmachowicz-Pawyza, D., Świerzakowska-Ambroziak, K. (2009), Analiza danych zastanych, Raport cząstkowy przygotowany w ramach projektu pt.Wspieranie aktywności zawodowej poprzez zarządzanie zjawiskiem migracji - analiza $w$ województwie ślaskim [Desk Research. An Interim Report in the Project on Migration Management Supporting Labour Activities-a Case ofthe Silesian Voivodeship], Katowice, http://www.migracje.otawagroup.pl/pliki/2009/12/2010-02-11.pdf(17.09.2013 r.).

Suchecki, B. (ed.), Ekonometria przestrzenna. Metody $i$ modele analizy danych przestrzennych [Spatial Econometrics. Methods and Models of Spatial Data Analysis]. Wydawnictwo C.H. BECK, Warszawa, 2010.

Sweeney, H. S., Goldstein, H. A., Accounting for Migration in Regional Occupational Employment Projections, “Annual Regional Science” 39: pp. 297-316, 2005.

Tobler, W., A Computer Model Simulating Urban Growth in the Detroit Region, "Economic Geography", 46(2), 1970.

Wright, R., Ellis, M., Nativity, Ethnicity and the Evolution of the Intraurban Division of Labor in Metropolitan Los Angeles, 1970-1990., "Geography”18, pp. 243-63, 1997.

Received: October 2013, revised: March 2015 